\title{
Diet selenium improves the antioxidant defense system of juveniles Nile tilapia (Oreochromis niloticus L.)
}

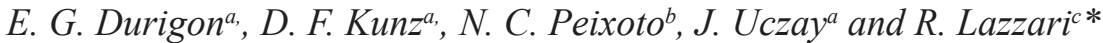 \\ ${ }^{a}$ Universidade Federal de Santa Maria - UFSM, Av. Roraima, 1000, Cidade Universitária, Bairro Camobi, \\ CEP 97105-900, Santa Maria, RS, Brasil \\ bDepartamento de Ciências da Saúde, Universidade Federal de Santa Maria - UFSM, Av. Roraima, 1000, \\ Cidade Universitária, Bairro Camobi, CEP 97105-900, Santa Maria, RS, Brasil \\ 'Departamento de Zootecnia e Ciências Biológicas, Universidade Federal de Santa Maria - UFSM, \\ Av. Independência, 3751, CEP 98300-000, Palmeira das Missões, RS, Brasil \\ *e-mail: rlazzari@ufsm.br
}

Received: November 12, 2017 - Accepted: December 18, 2017 - Distributed: August 31, 2019

\begin{abstract}
From the advancement of tilapia production in recent years, diets are sought that allow the maximum growth, improving health and fish quality. In this study growth, biochemical, hematological and oxidative parameters were evaluated of tilapia fed with increasing selenium levels: $0.53,0.86,1.04$ and $1.22 \mathrm{mg} \mathrm{kg}^{-1}$. It was used 400 juveniles (initial weight $=36.51 \pm 10.88 \mathrm{~g}$ ), fed for six weeks. There was no effect of selenium on fish growth, biochemical and hematological parameters. In the oxidative parameters, there was an increase in non-protein thiols and a decrease in malondialdehyde levels, evidencing antioxidant effects of selenium. The diet selenium levels above $0.86 \mathrm{mg} \mathrm{kg}^{-1}$ improved the antioxidant system and does not affect to biochemical, hematological and growth parameters of tilapia juveniles.
\end{abstract}

Keywords: health, Oreochromis niloticus, oxidative stress, performance, sodium selenite.

\section{Selênio na dieta melhora o sistema de defesa antioxidante de juvenis de Tilápia do Nilo (Oreochromis niloticus L.)}

\section{Resumo}

Com o avanço da produção de tilápia nos últimos anos, buscam-se dietas que possibilitem o máximo crescimento, saúde e qualidade do pescado. Neste trabalho foram avaliados parâmetros de crescimento, bioquímicos, sanguíneos e oxidativos de tilápias alimentadas com níveis crescentes de selênio: 0,53, 0,86, 1,04 e 1,22 $\mathrm{mg} \mathrm{kg}^{-1}$. Foram utilizados 400 juvenis (peso inicial $=36,51 \pm 10,88 \mathrm{~g}$ ), alimentados durante seis semanas. Não ocorreu efeito do selênio no crescimento, nem nos parâmetros bioquímicos e hematológicos dos peixes. Nos parâmetros oxidativos, ocorreu aumento nos níveis de tióis não-proteicos e diminuição de malondialdeído, evidenciando efeitos antioxidantes do selênio. Os níveis de selênio acima de $0.86 \mathrm{mg} \mathrm{kg}^{-1}$ melhoram o sistema antioxidante dos peixes e não compromete os parâmetros bioquímicos, sanguíneos e de crescimento de juvenis de tilápia.

Palavras-chave: desempenho, estresse oxidativo, Oreochromis niloticus, saúde, selenito de sódio.

\section{Introduction}

Brazil stands out as one of the countries with the largest quantity of flooded area that can be used for aquaculture. However, per capita fish consumption in Brazil is relatively low at around $11.17 \mathrm{~kg} /$ year (IBGE, 2015). Even so, according to estimates by the FAO in 2016 (FAO, 2016), it shows that among Latin American countries Brazil will have the highest aquaculture growth (104\%) by 2025, surpassing countries like Mexico and Argentina. According to the IBGE (2015) the volume produced by the Brazilian fish farming represents almost $70 \%$ of all national aquaculture, with 483.24 tons of fish. Statistics assert that, in 2015, Brazil produced 483,000 tons of fish. Tilapia contributed with $45 \%$ of production (Brasil, 2017).
Much of the tilapia production occurs in intensive practices, however, there are problems, especially in early stages, as disease outbreaks (Amlashi et al., 2011). Currently the concept of functional foods has been applied in the food industry for production animals, because diets in addition to meeting the nutritional requirements, also need to improve the health of farmed fish (Ibrahem et al., 2010; Al-Thobaiti et al., 2018).

The high cost of fish feed still is one of the great difficulties, so, it has been sought ever more efficient strategies to minimize these costs, including to know the needs of each nutrient for each species (Portz et al., 2000; Aride et al., 2018; Brasil, 2017). 
Selenium is a micromineral essential for fish growth (Hamilton, 2004). This element is a constituent of the enzyme glutathione peroxidase (GPx), an antioxidant enzyme that acts against reactive oxygen species (ROS) (Rider et al., 2009). Optimal level of selenium for fish varies from 0.21 to $1.18 \mathrm{mg} \mathrm{kg}^{-1}$ of diet (Borba et al., 2013). Selenium is a detoxifying of heavy metals such as cadmium and mercury (Southworth et al., 2000). The inclusion of larger amounts of selenium may also save the amount of vitamin E, because both act as antioxidants (Lin and Shiau, 2009).

Selenium deficiency usually results in growth and of activity of enzyme GPx reductions (NRC, 2011). High levels of selenium in the diet may also have a toxic effect, resulting in growth and feed efficiency reduced and mortality increased (Watanabe et al., 1997). Studies have shown that the optimum and toxic levels of selenium are very close (Borba et al., 2013).

The importance of selenium goes beyond fish nutrition. For striped bass (Morone saxatilis), there was a high accumulation of selenium in the muscle, regardless of use, if inorganic or organic (Cotter et al., 2008). This result suggests that the fish meat can become a good functional food, because its accumulation of selenium may provide increased antioxidant potential of this product.

In this context, the aim of this study was to determine whether the addition of selenium, at higher levels than those commonly used in commercial fish feed $\left(0.53 \mathrm{mg} \mathrm{kg}^{-1}\right)$, in tilapia juveniles considering growth, oxidative system and hematological and biochemical parameters.

\section{Materials and Methods}

The feeding trial was conducted at the Fish Farming Laboratory at UFSM, Campus Palmeira das Missões in a water recirculation system. The water recirculation system consisted of 16 tanks ( $250 \mathrm{~L}$ ) (four replicates per treatment) with individual inflow and outflow outlets, biological filters and thermostats for temperature control of water $\left(26\right.$ to $\left.28^{\circ} \mathrm{C}\right)$.

It was used 400 tilapia juveniles (Oreochromis niloticus), with average weight of $36.51 \pm 10.88 \mathrm{~g}$ ( 25 per tank). Before the experiment, the animals underwent two-week adaptation period. During all manipulations, fish were anesthetized with benzocaine (100 $\mathrm{mg} \mathrm{L}^{-1}$ ) (Delbon, 2006). The total experiment time lasts 42 days.

To make diets, the ingredients were mixed in a horizontal mixer. During this process, vitamin and mineral pre-mix, oil and water were added to the ingredients. The paste for all treatments was pelletized, and the pellets were dried at $55^{\circ} \mathrm{C}$ for $24 \mathrm{~h}$. After drying, the diets were stored in closed glass containers at $-15^{\circ} \mathrm{C}$. Sodium selenite $\left(\mathrm{Na}_{2} \mathrm{SeO}_{3}\right.$, chemical compost presents in commercial diets) levels added at the diets were $1.15 ; 1.55$ and $1.95 \mathrm{mg} \mathrm{kg}^{-1}$. The selenium level in the diet ingredients, including soya, meat, bones, wheat and corn meals, is estimated in $0.35 \mathrm{mg} \mathrm{kg}^{-1}$ (Rostagno, 2011). The total selenium level (ingredients + added) in control diet was $0.53 \mathrm{mg} \mathrm{kg}^{-1}$. Thus, considering the added selenium and the selenium present in ingredients, the levels were 0.53 (control diet), $0.86,1.04$ and $1.22 \mathrm{mg} \mathrm{kg}^{-1}$.

Fish received $3 \%$ of their body weight in feed per day (Table 1), divided into 3 meals: at 08:00 h am, 01:00 and 05:00 h pm. In order to remove excess feces and other dirts, it was realized the cleaning of tanks, which performed by siphoning. The amount of feed per experimental unit was measured every week by weighing all fish in each experimental unit.

The following animal performance parameters were analyzed: total length (TL), standard length (SL), specific growth rate (SGR), daily weight gain (DWG) and total weight gain (TWG). These parameters were measured and calculated according to Lazzari et al. (2008).

Blood collection was performed in the end of the trial, it was used 10 fish randomly per treatment. Five minutes

Table 1. Diet composition used in the tests with tilapia juveniles.

\begin{tabular}{|c|c|c|c|c|c|}
\hline Ingredients & $\mathrm{Se}_{0.53}$ & $\mathrm{Se}_{0.86}$ & $\mathrm{Se}_{1.04}$ & $\mathrm{Se}_{1.22}$ & $\operatorname{Se}\left(\mathrm{mg} \mathrm{kg}^{-1}\right)^{*}$ \\
\hline Soya meal $(\%)$ & 40 & 40 & 40 & 40 & 0.18 \\
\hline Meat and bones meal (\%) & 30 & 30 & 30 & 30 & 0.11 \\
\hline Wheat meal (\%) & 15 & 15 & 15 & 15 & 0.05 \\
\hline Corn meal (\%) & 10 & 10 & 10 & 10 & 0.01 \\
\hline Soya oil (\%) & 3 & 3 & 3 & 3 & 0 \\
\hline Vitamins and minerals** $(\%)$ & 1 & 1 & 1 & 1 & 0 \\
\hline Selenite of sodium $\left(\mathrm{mg} \mathrm{kg}^{-1}\right)^{* * *}$ & 0.4 & 1.15 & 1.55 & 1.95 & - \\
\hline Selenium $* * * *\left(\mathrm{mg} \mathrm{kg}^{-1}\right)$ & 0.53 & 0.86 & 1.04 & 1.22 & - \\
\hline Shell meal (\%) & 0.4 & 0.4 & 0.4 & 0.4 & 0 \\
\hline $\mathrm{NaCl}(\%)$ & 0.4 & 0.4 & 0.4 & 0.4 & 0 \\
\hline Lisin $(\%)$ & 0.1 & 0.1 & 0.1 & 0.1 & 0 \\
\hline Vitamin C (\%) & 0.1 & 0.1 & 0.1 & 0.1 & 0 \\
\hline
\end{tabular}

Selenium of the ingredients used in the diet ( $\mathrm{mg} \mathrm{kg}^{-1}$ in natural matter) based on Rostagno (2011). **Vitamin and mineral mix (guarantee levels per $\mathrm{kg}$ of product) - folic acid: $250 \mathrm{mg}$; pantothenic acid: 5,000 mg; antioxidant: $0.60 \mathrm{~g}$; biotin: $125 \mathrm{mg}$; cobalt: $25 \mathrm{mg}$; copper: 2,000 mg; iron: $820 \mathrm{mg}$; iodine: $100 \mathrm{mg}$; manganese: 3,750 mg; niacin: 5,000 mg; selenium: $75 \mathrm{mg}$; vitamin A: 1,000,000 IU; vitamin E: $120 \mathrm{mg}$, vitamin B1: $1,250 \mathrm{mg}$; vitamin B12: 3,750 $\mu \mathrm{g}$; vitamin B2: 2,500 mg; vitamin B6: 2,485 mg; vitamin D3: 500,000 UI; vitamin K: $500 \mathrm{mg}$; zinc: $17,500 \mathrm{mg}$. *** Addedsodium selenite in diets. ****Selenium amount in diets considering the added selenium plus the amount of selenium estimated in the ingredients (Rostagno, 2011). 
before blood collection, the animals were removed from the tank and anesthetized with benzocaine $\left(20 \mathrm{mg} \mathrm{L}^{-1}\right)$. The collection was performed by puncturing flow using an EDTA solution of $10 \%$ as an anticoagulant agent. It was analyzed the hematocrit, hemoglobin (cianometahemoglobin method, commercial kit Doles ${ }^{\circledR}$ ), blood cells total number and hematimetric indices [mean corpuscular volume (MCV), mean corpuscular hemoglobin $(\mathrm{MCH})$ and mean corpuscular hemoglobin concentration (MCHC)].

Oxidative parameters evaluated were: measurement of substances that react to thiobarbituric acid (TBARS, expressed as level of malondialdehyde, MDA) (Wills, 1987) and non-protein thiols (NPSH) (Ellman, 1959). Biochemical parameters triglycerides and cholesterol were determined by enzymatic methods with commercial kits Labtest ${ }^{\circledR}$.

The physical and chemical water parameters were within the recommended for the species (El-Sayed, 2006), the temperature in the morning and afternoon were respectively $24.83 \pm 2.64$ and $25.34 \pm 2.18{ }^{\circ} \mathrm{C}$; dissolved oxygen $4.96 \pm 0.78 \mathrm{mg} \mathrm{L}^{-1}$; ammonium $0.24 \pm 0.07 \mathrm{mg} \mathrm{L}^{-1}$; total alkalinity $56.73 \pm 9.81 \mathrm{mg} \mathrm{L}^{-1}$, total hardness $65.67 \pm 26.97 \mathrm{mg} \mathrm{L}^{-1}$ and acid water $15.87 \pm 1.26 \mathrm{mg} \mathrm{L}^{-1}$.

The data were submitted to the Shapiro-Wilk normality test. When they had normal distribution, values were analyzed by polynomial regression. When they had not normally distributed, the data were analyzed $(\mathrm{p}<0.05)$ by Kruskall-Wallis ANOVA and subsequently submitted to the Dunnett's test. The analysis was performed using the statistical package Statistical Analysis System ${ }^{\circledR}$.

\section{Results}

Growth parameters (weight, TL, SL, SGR, DWG and TWG) showed no difference among the tested levels of selenium (Table 2). Evaluated hematological parameters (hematocrit, hemoglobin and $\mathrm{MCHC}$ ) do not differed from the control treatment (Table $3 ; \mathrm{p}>0.05$ ). Erythrocytes number decreased with the selenium addition and $\mathrm{MCV}$ and $\mathrm{MCH}$ presented increased in comparation with control group (Table 3; $\mathrm{p}=0.03 ; \mathrm{p}=0.02$ and $\mathrm{p}=0.004$, respectively). Biochemical parameters (triglycerides and cholesterol) also showed no difference compared to the control group (Table 3; $\mathrm{p}>0.05$ ).

It was observed decrease for MDA in the gills ( $p=0.0048$ ) for the levels of 1.04 and $1.22 \mathrm{mg} \mathrm{kg}^{-1}$ of selenium compared to control (Table 4). To muscle, MDA decreased levels of 0.86, 1.04 and $1.22 \mathrm{mg} \mathrm{kg}^{-1}$ (Table 4; $p=0.02)$. There were no changes in the levels of MDA in the liver $(\mathrm{p}>0.05)$.

There was an increase of NPSH in the gills and muscle of tilapia fed with levels 1.04 and $1.22 \mathrm{mg} \mathrm{kg}^{-1}$ when compared to the control treatment (Table $4 ; p=0.0067$ and $\mathrm{p}=0.0002$ ). In the brain, only at the level of $0.86 \mathrm{mg} \mathrm{kg}^{-1}$ showed increased in amount of NPSH $(p=0.0035)$. There was not difference in level of hepatic NPSH when compared the treatment groups.

Table 2. Growth parameters of tilapia fed with different selenium levels.

\begin{tabular}{lrrrr}
\hline \multirow{2}{*}{ Variables } & \multicolumn{4}{c}{ Levels of selenium $\mathbf{~} \mathbf{m g ~ k g}^{-\mathbf{1}}$ of diet) } \\
\cline { 2 - 5 } & $\mathbf{0 . 5 3}$ & $\mathbf{0 . 8 6}$ & $\mathbf{1 . 0 4}$ & $\mathbf{1 . 2 2}$ \\
\hline Weight (g) & $84.68 \pm 8.22$ & $75.14 \pm 5.34$ & $82.36 \pm 5.71$ & $82.16 \pm 4.69$ \\
TL (cm) & $17.75 \pm 0.47$ & $17.22 \pm 0.34$ & $16.88 \pm 0.50$ & $17.79 \pm 0.28$ \\
SL (cm) & $14.85 \pm 0.30$ & $14.48 \pm 0.31$ & $13.95 \pm 0.47$ & $15.01 \pm 0.26$ \\
DWG (g) & $1.33 \pm 0.11$ & $1.20 \pm 0.07$ & $1.29 \pm 0.10$ & $1.28 \pm 0.09$ \\
SGR (\%) & $2.29 \pm 0.16$ & $2.33 \pm 0.12$ & $2.26 \pm 0.14$ & $2.25 \pm 0.09$ \\
TWG (g) & $46.63 \pm 3.89$ & $41.91 \pm 2.47$ & $45.00 \pm 3.77$ & $44.76 \pm 3.38$ \\
\hline
\end{tabular}

The data are presented as mean \pm standard deviation. $\mid$ There is no significant differences among the groups. TL $=$ total length; $\mathrm{SL}=$ standard length; $\mathrm{DWG}=$ daily weight gain; $\mathrm{SGR}=$ specific growth rate; $\mathrm{TWG}=$ total weight gain.

Table 3. Hematological and biochemical parameters of tilapia fed with different selenium levels.

\begin{tabular}{|c|c|c|c|c|c|}
\hline \multirow{2}{*}{ Variables } & \multicolumn{4}{|c|}{ Levels of selenium (mg kg-1 of diet) } & \multirow{2}{*}{$\mathbf{p}$} \\
\hline & 0.53 & 0.86 & 1.04 & 1.22 & \\
\hline Hematocrit $(\%)$ & $38.8 \pm 6.11$ & $36.77 \pm 3.68$ & $37.21 \pm 3.89$ & $39.77 \pm 3.51$ & NS \\
\hline Hemoglobin $\left(\mathrm{g} \mathrm{dL}^{-1}\right)$ & $7.41 \pm 1.02$ & $7.37 \pm 0.97$ & $7.46 \pm 0.73$ & $7.77 \pm 0.92$ & NS \\
\hline Eryhrocytes $\left(\mathrm{x} 10^{6} \mu \mathrm{L}^{-1}\right)$ & $3.34 \pm 1.05$ & $2.03 \pm 0.60 *$ & $2.13 \pm 0.71 *$ & $2.31 \pm 0.69^{*}$ & 0.03 \\
\hline MCV (fL) & $118.03 \pm 25.67$ & $195.13 \pm 40.19 *$ & $164.55 \pm 37.50$ & $180.03 \pm 53.90^{*}$ & 0.02 \\
\hline $\mathrm{MCH}(\mathrm{pg})$ & $21.30 \pm 4.60$ & $33.59 \pm 7.51^{*}$ & $35.77 \pm 8.88^{*}$ & $36.23 \pm 7.48^{*}$ & 0.004 \\
\hline $\mathrm{MCHC}(\%)$ & $19.34 \pm 1.24$ & $19.96 \pm 2.55$ & $21.70 \pm 3.26$ & $20.62 \pm 2.01$ & NS \\
\hline Triglycerides (mg dL $\left.{ }^{-1}\right)$ & $60.91 \pm 14.98$ & $45.53 \pm 12.52$ & $52.28 \pm 19.65$ & $49.83 \pm 8.83$ & NS \\
\hline Cholesterol (mg dL-1) & $104.58 \pm 21.06$ & $104.95 \pm 13.60$ & $100.81 \pm 22.31$ & $104.47 \pm 19.67$ & NS \\
\hline
\end{tabular}

*Significantly different from diet with $0.53 \mathrm{mg} \mathrm{kg}^{-1}$. The data are presented as mean \pm standard deviation. Data were analyzed $(\mathrm{p}<0.05)$ by ANOVA Kruskal-Wallis and subsequently subjected to Dunnett's test. $\mathrm{MCV}=$ mean corpuscular volume, $\mathrm{MCH}=$ mean corpuscular hemoglobin, $\mathrm{MCHC}=$ mean corpuscular hemoglobin concentration and $\mathrm{NS}=$ no significant $(\mathrm{P}>0.05)$. 
Table 4. Oxidative parameters of tilapia fed with different selenium levels.

\begin{tabular}{|c|c|c|c|c|c|}
\hline \multirow{2}{*}{ Variables } & \multicolumn{4}{|c|}{ Levels of selenium ( $\mathrm{mg} \mathrm{kg}^{-1}$ of diet) } & \multirow[b]{2}{*}{$\mathbf{p}$} \\
\hline & 0.53 & 0.86 & 1.04 & 1.22 & \\
\hline \multicolumn{6}{|l|}{ Liver } \\
\hline MDA & $0.50 \pm 0.03$ & $0.57 \pm 0.02$ & $0.51 \pm 0.04$ & $0.44 \pm 0.02$ & NS \\
\hline NPSH & $5.47 \pm 0.87$ & $8.03 \pm 1.00$ & $5.93 \pm 0.42$ & $5.44 \pm 0.61$ & NS \\
\hline \multicolumn{6}{|l|}{ Gills } \\
\hline MDA & $2.26 \pm 0.16$ & $2.54 \pm 0.13$ & $1.76 \pm 0.11^{*}$ & $1.53 \pm 0.08 *$ & 0.0048 \\
\hline NPSH & $160.07 \pm 33.20$ & $234.54 \pm 38.30$ & $303.73 \pm 41.93^{*}$ & $525.60 \pm 63.82 *$ & 0.0067 \\
\hline \multicolumn{6}{|l|}{ Muscle } \\
\hline MDA & $0.57 \pm 0.21$ & $0.18 \pm 0.02 *$ & $0.13 \pm 0.01 *$ & $0.09 \pm 0.006^{*}$ & 0.02 \\
\hline NPSH & $2246.77 \pm 130.51$ & $2495.54 \pm 243.43$ & $3223.24 \pm 169.61 *$ & $3177.04 \pm 234.35^{*}$ & 0.0002 \\
\hline \multicolumn{6}{|l|}{ Brain } \\
\hline NPSH & $12.72 \pm 2.50$ & $19.28 \pm 2.63^{*}$ & $16.21 \pm 1.79$ & $14.10 \pm 1.23$ & 0.035 \\
\hline
\end{tabular}

*Significantly different from diet with $0.53 \mathrm{mg} \mathrm{kg}^{-1}$. The data are presented as mean \pm standard deviation. MDA = malondialdehyd measured for reactive species to thiobarbituric acid; NPSH: non-protein thiols and NS $=$ no significant $(\mathrm{P}>0.05)$. Data were analyzed $(\mathrm{p}<0.05)$ by ANOVA Kruskal-Wallis and subsequently subjected to Dunnett's test. The results are expressed in $\mu \mathrm{mol} \mathrm{mg^{-1 }}$ protein.

\section{Discussion}

Increased levels of selenium in the diet not caused prejudice to the growth parameters in juvenile tilapia. This result may suggest that tilapia has a greater need of selenium, requiring larger doses of this mineral in diets to have some effect on the growth parameters. The concentration of $0.86 \mathrm{mg} \mathrm{kg}^{-1}$ (less concentration) of selenium added via diet to fry matrinxã (Bryncon orbignyanus) also did not cause any of the characteristic effects of selenosis described in the literature (Monteiro et al., 2007).

In this trial, was not observed toxicity signals in fishes caused by selenium, as reduced growth, mortality or hematologic abnormalities (NRC, 2011). Doses of selenium a bit higher than the required amount, can cause toxicity in fish, thus the difference between the requirement and the minimum dose is very small. This work reveals that the tilapia tolerates $1.22 \mathrm{mg} \mathrm{kg}^{-1}$ of selenium in the diet, without losses in growth.

Lee et al. (2016) fed juveniles of tilapia with feed containing $1.04 \mathrm{mg} \mathrm{kg}^{-1}$ selenium, equivalent to a concentration employed here, and observed that the animals had a specific weight gain and a specific growth rate better than those observed for the group control. Such differences in comparison with the present research can be attributed to the chemical form of the added selenium, to the developmental stage of the fish or to the time of treatment. As for the mineral form used, organic in that work and inorganic in this work, whose bioavailability is greater for the first (Watanabe et al., 1997), which optimizes the use of the same.

Deficiency or excess selenium in the fish organism cause decreased in hematocrit and hemoglobin, consequently caused anemia and erythrocyte fragility (Watanabe et al., 1997; Lemly, 2002). The lack of this mineral can affect the erythrocyte membrane protection account the ROS due to higher accumulation of hydroperoxide in fish body (Rider et al., 2009). The excess of selenium (mainly in form of sodium selenite) reacts with glutathione to produce superoxide and hydrogen peroxide $\left(\mathrm{H}_{2} \mathrm{O}_{2}\right)(\mathrm{Lin}$ and Spallholz, 1993) and these compounds also damage the membranes of erythrocytes. In juveniles of pacu (Piaractus mesopotamicus) selenium in the quantity of $0.6 \mathrm{mg} \mathrm{kg}^{-1}$ promoted an increase in the total count of erythrocytes and this was attributed to an increase in GPx activity (Biller-Takahashi et al., 2015). In this study, hemoglobin, hematocrit and MCHC showed no difference and consequently the fish showed no signals of anemia. Though the erythrocytes number and the MCV and $\mathrm{MCH}$ hematimetric indices have been affected, a compensatory mechanism occurred, a decrease of number with size and hemoglobin level higher per element.

In our investigation, the hematological variables were not modified by the treatments, which indicates the protection, with a lower level of MDA and a higher level of NPSH, conferred to the animals exposed to selenium in part of the tissues analyzed. This can be exemplified by the hematocrit, which evaluates the blood volume occupied by the erythrocytes, and the MCHC, which estimates the volume occupied by hemoglobin in them, suggesting that the erythrocyte membrane may also have been the target of the studied mineral, since its integrity was verified through the measurement of these parameters.

Gills and muscle showed lower production level of MDA and increased of NPSH when fishes were feed with larger quantities of selenium. However, when these parameters were measured in the liver did not differ. Decreased in levels of MDA and increased in levels of NPSH in the gills may be the due this organ is the major route of excretion of selenium (Lall, 2002). Thus, the mineral is used in this tissue to contribute to the antioxidant defense system.

The lowest amount of NPSH in the liver can be explained by the fact that selenium is stored directly in various tissues, except in this organ (Watanabe et al., 
1997). Protection against lipid peroxidation is different between tissues and in some tissues defense appears to be less efficient (Maranesi et al., 2004; Oliveira et al., 2008).

As for quantified lipids, selenium also had no effect on plasma cholesterol levels, indicative of renal and hepatic toxicity, and triglycerides, indicative of nutritional status. Similarly, in carp, organic selenium did not cause increases in cholesterol and triglyceride levels (Ashouri et al., 2015). This chemical element does not appear to be potentially toxic, since metals such as cadmium, copper, chromium, silver and zinc, at concentrations well below $0.05 \mathrm{mg} \mathrm{L}^{-1}$, caused increases in serum levels of tilapia cholesterol (Öner et al., 2008).

Studies have shown that high levels of selenium, favor the accumulation of this mineral in fish muscle. In hybrid striped bass adding selenium (regardless of organic or inorganic origin) at the level of $3.2 \mathrm{mg} \mathrm{kg}^{-1}$ caused a greater accumulation of this mineral in the musculature (Cotter et al., 2008). This greater accumulation of selenium in addition to contributing to the maintenance of the antioxidant system, it is also important for human nutrition, since muscles with higher levels of this mineral are interesting to the health of people who will consume.

The NPSH increased in the gills and muscle. The NPSH are an indirect measure of the amount of glutathione, and an important non-enzymatic antioxidant that acts on the second line of defense, reducing ROS and is also a substrate for the enzyme GPx and glutathione-S-transferase (Elia et al., 2006). The selenium in the diet of rats at a dosage of $200 \mu \mathrm{g} \mathrm{kg}^{-1}$ promoted a significant increase of the content of total thiols (-SH), besides the reduction of lipid peroxidation in plasma, liver, kidneys, and testes (El-Demerdash et al., 2004). Selenium and vitamin E are important in the metabolism of sulfur amino acids such as methionine and cysteine, which are precursors NPSH (Dimitrov, 1987; Dandapat et al., 2000). The biosynthesis of glutathione is mainly determined by the concentration of amino acid precursors and competes with the amino acids available for protein synthesis (Roehrs et al., 2004). Thus, a larger amount of selenium via diet might have stimulated the synthesis of NPSH.

The addition of selenium in diets for farmed fish is recommended for the improvement of health conditions of these animals. Selenium supplementation improves cellular protection against oxidative stress and contributes to the increase in antioxidant defenses of the organisms (Monteiro et al., 2007). The increased in production of NPSH and the decrease of MDA indicate that there was a decrease in ROS. Selenium is a cofactor of the enzyme GPx, which is involved in the mechanism of ROS neutralization (Rider et al., 2009). Thus, an increase in the amount of selenium in the body of tilapia juveniles, can stimulate the antioxidant defense system increasing efficiency in combating the ROS.

In conclusion, the diet selenium levels above $0.86 \mathrm{mg} \mathrm{kg}^{-1}$ improved the antioxidant status of the fishes and does not affect to biochemical, hematological and growth parameters of tilapia juvenile.

\section{Acknowledgements}

The author E. G. Durigon received fellowship from the CNPq/PIBIC program.

\section{References}

AL-THOBAITI, A., AL-GHANIM, K., AHMED, Z., SULIMAN, E.M. and MAHBOOB, S., 2018. Impact of replacing fish meal by a mixture of different plant protein sources on the growth performance in Nile Tilapia (Oreochromis niloticus L.) diets. Brazilian journal of biology $=$ Revista brasleira de biologia, vol. 78, no. 3, pp. 525-534. PMid:29069165.

AMLASHI, A.S., FALAHATKAR, B., SATTARI, M. and GILANI, M.H.T., 2011. Effect of dietary vitamin E on growth, muscle composition, hematological and immunological parameters of sub-yearling beluga Huso huso L. Fish \& Shellfish Immunology, vol. 30, no. 3, pp. 807-814. http://dx.doi.org/10.1016/j.fsi.2011.01.002. PMid:21232609.

ARIDE, P.H.R., OLIVEIRA, A.M., BATISTA, R.B., FERREIRA, M.S., PANTOJA-LIMA, J., LADISLAU, D.S., CASTRO, P.D.S. and OLIVEIRA, A.T., 2018. Changes on physiological parameters of tambaqui (Colossoma macropomum) fed with diets supplemented with Amazonian fruit Camu camu (Myrciaria dubia). Brazilian journal of biology $=$ Revista brasleira de biologia, vol. 78, no. 2, pp. 360-367. PMid:28954015.

ASHOURI, S., KEYVANSHOKOOH, S., SALATI, A.P., JOHARI, S.A. and PASHA-ZANOOSI, H., 2015. Effects of different levels of dietary selenium nanoparticles on growth performance, muscle composition, blood biochemical profiles and antioxidant status of common carp (Cyprinus carpio). Aquaculture, vol. 446, no. 1, pp. 25-29. http://dx.doi.org/10.1016/j.aquaculture.2015.04.021.

BILLER-TAKAHASHI, J.D., TAKAHASHI, L.S., MINGATTO, F.E. and URBINATI, E.C., 2015. The immune system is limited by oxidative stress: Dietary selenium promotes optimal antioxidative status and greatest immune defense in pacu (Piaractus mesopotamicus). Fish \& Shellfish Immunology, vol. 47, no. 1, pp. 360-367. http:// dx.doi.org/10.1016/j.fsi.2015.09.022. PMid:26370542.

BORBA, M.R., SÁ, M.V.C. and ABREU, J.S., 2013. Vitaminas e minerais. In: D.M. FRACALOSSI and J.E.P. CYRINO, ed. Nutriaqua: nutrição e alimentação de espécies de interesse para a aquicultura brasileira. Florianópolis: Sociedade Brasileira de Aquicultura e Biologia Aquática. 375 p.

BRASIL, 2017 [viewed 7 December 2017]. Produção de peixes no Brasil cresce com apoio de pesquisas da Embrapa [online]. Available from: http://www.brasil.gov.br/economiae-emprego/2017/01/producao-de-peixes-no-brasil-cresce-comapoio-de-pesquisas-da-embrapa

COTTER, P.A., CRAIG, S.R. and MCLEAN, E., 2008. Hyper accumulation of selenium in hybrid striped bass: a functional food for aquaculture? Aquaculture Nutrition, vol. 14, no. 3, pp. 215-222. http://dx.doi.org/10.1111/j.1365-2095.2007.00520.x.

DANDAPAT, J., CHAINY, G.B.N. and JANARDHANA RAO, K.J., 2000. Dietary vitamin-E modulates antioxidant defense system in giant freshwater prawn, Macrobrachium rosenbergii. Comparative Biochemistry and Physiology. Toxicology \& Pharmacology : CBP, vol. 127, no. 1, pp. 101-115. http://dx.doi. org/10.1016/S0742-8413(00)00132-8. PMid:11081417.

DELBON, M.C. 2006. Ação da benzocaína e do óleo de cravo sobre parâmetros fisiológicos de tilápia, Oreochromis niloticus. 
Jaboticabal: Universidade do Estado de São Paulo, 78 p. Dissertação de Mestrado em Aquicultura.

DIMITROV, M., 1987. Intensive polyculture of common carp, Cyprinus carpio L., silver carp, Hypophthalmichthys molitrix (Val.) and black buffalo, Ictiobus niger (Raf.). Aquaculture, vol. 65, no. 2, pp. 119-125. http://dx.doi.org/10.1016/0044-8486(87)90256-0.

EL-DEMERDASH, F.M., YOUSEF, M.I., KEDWANY, S.F. and BAGHDADI, H.H., 2004. Cadmium-induced changes in lipid peroxidation, blood hematology, biochemical parameters and semen quality of male rats: protective role of vitamin $\mathrm{E}$ and $\beta$-carotene. Food and Chemical Toxicology, vol. 42, no. 10, pp. 1563-1571. http://dx.doi.org/10.1016/j.fct.2004.05.001. PMid:15304303.

ELIA, A.C., GALARINI, R., DORR, A.J.M. and TATICCHI, M.I., 2006. Bioaccumulation of heavy metals, organochlorine pesticides, and detoxication biochemical indexes in tissues of Ictalurus melas of Lake Trasimeno. Bulletin of Environmental Contamination and Toxicology, vol. 76, no. 1, pp. 132-139. http://dx.doi.org/10.1007/s00128-005-0899-1. PMid:16404671.

ELLMAN, G.L., 1959. Tissue sulphydryl groups. Archives of Biochemistry and Biophysics, vol. 82, no. 1, pp. 70-77. http:// dx.doi.org/10.1016/0003-9861(59)90090-6. PMid:13650640.

EL-SAYED, E.M. 2006. Tilapia culture. Massachusetts: CABI. 275 p. http://dx.doi.org/10.1079/9780851990149.0000.

FOOD AND AGRICULTURE ORGANIZATION - FAO, 2016. El estado mundial de la pesca y la acuicultura 2016: contribución a la seguridad alimentaria y la nutrición para todos. Roma: FAO. 224 p.

HAMILTON, S.J., 2004. Review of selenium toxicity in the aquatic food chain. The Science of the Total Environment, vol. 326, no. 1-3, pp. 1-31. http://dx.doi.org/10.1016/j.scitotenv.2004.01.019. PMid:15142762.

IBRAHEM, M.D., FATHI, M., MESALHY, S. and ABD ELATY, A.M., 2010. Effect of dietary supplementation of inulin and vitamin $\mathrm{C}$ on the growth, hematology, innate immunity, and resistance of Nile tilapia (Oreochromis niloticus). Fish \& Shellfish Immunology, vol. 29, no. 2, pp. 241-246. http://dx.doi. org/10.1016/j.fsi.2010.03.004. PMid:20371294.

INSTITUTO BRASILEIRO DE GEOGRAFIA E ESTATÍSTICA - IBGE, 2015. Pesquisa pecuária municipal 2015. Brasília: IBGE, vol. 43, $47 \mathrm{p}$.

LALL, S.P. 2002. The mineral nutrition. In: J.E. HALVER and R.W. HARDY, eds. Fish nutrition. 3. ed. Washington: National Academy Press, pp. 259-308.

LAZZARI, R., RADÜNZ NETO, J., PEDRON, F.A., VEIVERBERG, C.A., BERGAMIN, G.T., LIMA, R.L., EMANUELLI, T. and STEFFENS, C., 2008. Desempenho e composição dos filés de jundiás (Rhamdia quelen) submetidos a diferentes dietas na fase de recria. Arquivo Brasileiro de Medicina Veterinária e Zootecnia, vol. 60, no. 2, pp. 477-484. http://dx.doi. org/10.1590/S0102-09352008000200030.

LEE, S., NAMBI, R.W., WON, S., KATYA, K. and BAI, S.C., 2016. Dietary selenium requirement and toxicity levels in juvenile Nile tilapia, Oreochromis niloticus. Aquaculture, vol. 461, no. 1, pp. 153-158. http://dx.doi.org/10.1016/j.aquaculture.2016.06.027.

LEMLY, A.D., 2002. Symptoms and implications of selenium toxicity in fish: the Belews Lake case example. Aquatic Toxicology, vol. 57, no. 1-2, pp. 39-49. http://dx.doi.org/10.1016/S0166445X(01)00264-8. PMid:11879937.
LIN, Y. and SPALLHOLZ, J.E., 1993. Generation of reactive oxygen species from the reaction of selenium compounds with thiols and mammary tumor cells. Biochemical Pharmacology, vol. 45, no. 2, pp. 429-437. http://dx.doi.org/10.1016/00062952(93)90080-G. PMid:8382065.

LIN, Y.H. and SHIAU, S.Y., 2009. Mutual sparing of dietary requirements for alpha-tocopherol and selenium in grouper Epinephelus malabaricus. Aquaculture, vol. 294, no. 3-4, pp. 242-245. http://dx.doi.org/10.1016/j.aquaculture.2009.06.002.

MARANESI, M., BOCHICCHIO, D., ZAMBONIN, L., TOLOMELLI, B. and CABRINI, L., 2004. Effects of different dietary amounts of LCPUFA n-3 and vitamin $B_{6}$ on lipid composition and antioxidant defences in rat kidney. The Journal of Nutritional Biochemistry, vol. 15, no. 7, pp. 396-401. http:// dx.doi.org/10.1016/j.jnutbio.2003.09.006. PMid:15219924.

MONTEIRO, D.A., RANTIN, F.T. and KALININ, A.L., 2007. Uso do selênio na dieta de matrinxã, Brycon cephalus. Revista Brasileira de Saúde e Produção Animal, vol. 8, no. 1, pp. 32-47.

NATIONAL RESEARCH COUNCIL - NRC, 2011. Nutrient requeriments of fish and shrimp. Washington: The National Academic Press. 376 p.

OLIVEIRA, M., PACHECO, M. and SANTOS, M.A., 2008. Organ specific antioxidant responses in golden grey mullet (Liza aurata) following a short-term exposure to phenanthrene. The Science of the Total Environment, vol. 396, no. 1, pp. 70-78. http:// dx.doi.org/10.1016/j.scitotenv.2008.02.012. PMid:18358514.

ÖNER, M., ATLI, G. and CANLI, M., 2008. Changes in serum biochemical parameters of freshwater fish Oreochromis niloticus following prolonged metal $(\mathrm{Ag}, \mathrm{Cd}, \mathrm{Cr}, \mathrm{Cu}, \mathrm{Zn})$ exposures. Environmental Toxicology and Chemistry, vol. 27, no. 2, pp. 360-366. http://dx.doi.org/10.1897/07-281R.1. PMid:18348636.

PORTZ, L., DIAS, C.T.S. and CYRINO, J.E.P., 2000. A brokenline model to fit fish nutrition requirements. Scientia Agricola, vol. 57, no. 4, pp. 601-607. http://dx.doi.org/10.1590/S010390162000000400002 .

RIDER, S.A., DAVIES, S.J., JHA, A.N., FISHER, A.A., KNIGHT, J. and SWEETMAN, J.W., 2009. Supra-nutritional dietary intake of selenite and selenium yeast in normal and stressed rainbow trout (Oncorhynchus mykiss): Implications on selenium status and health responses. Aquaculture, vol. 295, no. 3-4, pp. 282-291. http://dx.doi.org/10.1016/j.aquaculture.2009.07.003.

ROEHRS, R., GUECHEVA, T.N., SAFFI, J. and HENRIQUES, J.A.P. 2004. Alvos redox-sensíveis nas cascatas de sinalização. In: M. SALVADOR, and J.A.P. HENRIQUES, eds. Radicais livres e a resposta celular ao estresse oxidativo. Canoas: ULBRA, pp. 161-184.

ROSTAGNO, H.S., 2011. Tabelas brasileiras para aves e suínos: composição de alimentos e exigências nutricionais. 3 . ed. Viçosa: Editora UFV.

SOUTHWORTH, G.R., PETERSON, M.J. and RYON, M.G., 2000. Long-term increased bioaccumulation of mercury in largemouth bass follows reduction of waterborne selenium. Chemosphere, vol. 41, no. 7, pp. 1101-1105. http://dx.doi.org/10.1016/S00456535(99)00562-7. PMid:10879829.

WATANABE, T., KIRON, V. and SATOH, S., 1997. Trace minerals in fish nutrition. Aquaculture, vol. 151, no. 1-4, pp. 185-207. http://dx.doi.org/10.1016/S0044-8486(96)01503-7.

WILLS, E.D. 1987. Evaluation of lipid peroxidation in lipids and biological membranes. In: K. Snell and B. Mullock, eds. Biochemical toxicology: a pratical approach. Oxford: IRL Press, pp. 127-152. 